\title{
PENGARUH RETURN ON ASSETS DAN KEPEMILIKAN INSTITUSIONAL TERHADAP PENGHINDARAN PAJAK PADA PERUSAHAAN INDUSTRI BARANG KONSUMSI YANG TERDAFTAR PADA BURSA EFEK INDONESIATAHUN 2017-2019
}

\author{
YAN CHRISTIN BR SEMBIRING ${ }^{1}$ \\ AGUSTINA FRANSISKA ${ }^{2}$ \\ ${ }^{1,2}$ Program studi Akuntansi Universitas Katolik Santo Thomas Medan \\ yanchristin11@gmail.com ${ }^{1}$, Agustinafransiska99@gmail.com ${ }^{2}$
}

\begin{abstract}
ABSTRAK
Penelitian ini dilakukan untuk membuktikan secara empiris ROA berpengaruh terhadap penghindaran pajak pada perusahaan industri barang konsumsi yang terdaftar di bursa efek Indonesia (BEI) tahun 2017- 2019. Dan Untuk membuktikan kepemilikan institusional berpengaruh terhadap penghindaran pajak pada perusahaan industri barang konsumsi yang terdaftar di bursa efek Indonesia (BEI) tahun 2017- 2019. Sample pada penelitian ini didapatkan dengan cara purposive sampling. Dengan jumlah sample 56 perusahaan. Metode analisis yang digunakan adalah persamaan regresi linier berganda dengan menggunakan SPSS 25. Dari hasil pengujian SPSS diketahui bahwa, nilai koefesien deterninasi (R square) sebesar 0,039, ini berarti ROA dan kepemilikan institusional bersama-sama mempengaruhi penghindaran pajak yaitu 3,9\%. Berdasarkan hasil analisis regresi linier berganda dapat disimpulkan bahwa ROA berpengaruh positif dan tidak signifikan terhadap penghindaran pajak perusahaan industri barang konsumsi yang terdaftar di Bursa Efek Indonesia tahun 2017-2019. Dan kepemilikan institusional berpengaruh negatif dan tidak signifikan terhadap penghindaran pajak perusahaan industri barang konsumsi yang terdaftar di Bursa Efek Indonesia tahun 2017-2019.
\end{abstract}

Kata kunci : $\quad$ Penghindaran Pajak, Return On Assets, dan Kepemilikan Institusional.

\section{PENDAHULUAN}

Di berbagai negara pajak merupakan sebuah penerimaan yang cukup besar. Begitu juga di negara Indonesia. Pajak merupakan salah satu unsur terbesar dalam penerimaan pemerintah Indonesia. Karena itulah pelaksanaan perpajakan sangat diatur oleh pemerintah Indonesia guna mempertahankan penerimaan negara. Pengertian pajak sediri diatur dalam Undang-Undang Republik Indonesia Nomor 28 Tahun 2007 Pasal 1, yaitu kontribusi wajib kepada negara yang terhutang oleh orang pribadi atau badan yang bersifat memaksa berdasarkan Undang-Undang, dengan tidak mendapatkan imbalan secara langsung dan digunakan untuk keperluan negara bagi sebesar-besarnya kemakmuran rakyat. Dari pengertian tersebut sudah sangat jelas bahwa pajak memiliki arti penting bagi negara. Dengan begitu, pemerintah Indonesia selalu menaikkan target penerimaan pajak dari tahun ke tahun.

Salah satu upaya pemerintah untuk meningkatkan penerimaan pajak adalah dengan selalu berupaya untuk melakukan perbaikan dan penyempurnaan atas peraturan-peraturan perpajakan di Indonesia. Perubahan-perubahan peraturan perpajakan yang dilakukan oleh pemerintah untuk memperbaiki sistem perpajakan dan meningkatkan jumlah penerimaan negara di bagian pajak ini disebut reformasi pajak. Reformasi pajak juga dilakukan dengan tujuan untuk meningkatkan kesadaran warga negara untuk berpartisipasi dalam proses pembangunan melalui pembayaran pajak. Akan tetapi, banyak warga negara yang masih menganggap pajak sebagai suatu beban. Perusahaan atau badan juga masih menganggap pajak sebagai beban yang akan mengurangi laba bersih perusahaan. Wajib pajak akan cenderung mencari cara untuk memperkecil pajak yang mereka bayar, baik itu legal maupun ilegal. Dari 
sisi perusahaan, tujuan perusahaan memperkecil pajak adalah untuk mencapai tingkat laba dan likuiditas yang ditargetkan perusahaan.

Perencanaan pajak adalah suatu sarana yang dilakukan wajib pajak dalam meminimalkan pajak yang terhutang melalui skema yang telah diatur dalam perundangundangan perpajakan. Perusahaan dapat melakukan banyak strategi dalam melakukan perencanaan pajak. Salah satu strategi Perencanaan pajak adalah penghindaran pajak (tax avoidance). Penghindaran pajak merupakan cara mengurangi pajak secara legal sesuai dengan perundang- undangan perpajakan. Praktik penghindaran pajak dilakukan dengan memanfaatkan kelemahan-kelemahan hukum pajak dan tidak melanggar peraturan perpajakan,

Banyaknya faktor yang mempengaruhi penghindaran pajak diantara return on assets selanjutnya disebut ROA dan kepemilikan institusional. ROA menurut Prastowo (2015) adalah rasio yang mengukur kemampuan perusahaan dalam memanfaatkan aktivanya untuk memperoleh laba. Rasio ini juga mengukur tingkat kembalian investasi yang telah dilakukan oleh perusahaan dengan menggunakan seluruh dana (aktiva) yang dimilikinya. Perusahaan dengan tingkat efisiensi yang tinggi dan memiliki pendapatan tinggi cenderung menghadapi beban pajak yang rendah. Rendahnya beban pajak dikarenakan perusahaan dengan pendapatan yang tinggi berhasil memanfaatkan keuntungan dari adanya insentif pajak dan pengurang pajak yang lain menurut Darmadi (2013).

Menurut Mardiasmo (2003) pengertian tax avoidance atau penghindaran pajak yang lain adalah suatu usaha meringankan beban pajak dengan tidak melanggar undang-undang yang ada. Menurut Robert H Anderson dalam zain (2008) penghindaran pajak (tax avoidance) merupakan cara mengurangi pajak yang masih dalam batas ketentuan peraturan perundangundangan perpajakan dan dapat dibenarkan terutama melalui perencanaan perpajakan".

Tarjo (2008), kepemilikan institusional adalah kepemilikan saham perusahaan yang dimiliki oleh institusi atau lembaga seperti perusahaan asuransi, bank, perusahaan investasi dan kepemilikan institusi lain. Adanya kepemilikan institusional diharapkan mampu menciptakan kontrol yang baik.

Dari uraian diatas maka akan dilakukan penelitian pada perusahaan industri barang konsumsi yang terdaftar dibursa efek Indonesia selama periode 2017-2019. Berdasarkan latar belakang penelitian diatas maka peneliti tertarik untuk mengambil judul "Pengaruh Return On Assets dan Kepemilikan Institusional Terhadap Penghindaran Pajak Pada Perusahaan Indutri Barang Konsumsi yang Terdaftar pada Bursa Efek Indonesia Pada Tahun 2017-2019.”

\section{TINJAUAN PUSTAKA DAN HIPOTESIS}

\section{Teori keagenan}

Jensen dan Meckling (1976) menjelaskan hubungan keagenan di dalam teori agensi bahwa perusahaan merupakan kumpulan kontrak antara pemilik sumber daya ekonomis (principal) dan manajer (agent) yang mengurus penggunaan dan pengendalian sumber daya tersebut. Principal sebagai penyedia dana untuk menjalankan perusahaan, mendelegasikan kebijakan keputusan kepada agent. Principal mempekerjakan Agent dalam perusahaan untuk melakukan tugas memaksimalkan laba perusahaan dan meningkatkan kemakmuran pemegang saham, sedangkan manajer perusahaan mempunyai kecenderungan untuk memperoleh keuntungan yang sebesar-besarnya dengan biaya pihak lain dan cenderung tidak menyukai resiko. Manajer tidak menanggung resiko atas kesalahan dalam pengambilan keputusan, resiko tersebut sepenuhnya ditanggung oleh pemegang saham (principal). Oleh karena itu, manajemen cenderung melakukan pengeluaran untuk kepentingan pribadinya, seperti peningkatan gaji dan status. Forum for Corporate Governance in Indonesia (2000) menyebutkan pemilik perusahaan atau pemegang saham hanya bertugas mengawasi dan memonitor jalannya perusahaan yang dikelola oleh manajemen. Konflik antara manajer dan 
pemegang saham sering mengatur manajemen puncak perusahaan untuk mengambil keputusan yang tidak dalam kepentingan terbaik pemegang saham, khususnya bila seorang yang oportunis terlibat dalam proses (Jensen and Meckling, 1976)

\section{Perpajakan}

Berdasarkan UU KUP nomor 28 tahun 2007 pasal 1 ayat 1, pengertian pajak adalah kontribusi wajib kepada Negara yang terutang oleh orang pribadi atau badan yang bersifat memaksa berdasarkan undang-undang, dengan tidak mendapatkan imbalan secara langsung dan digunakan untuk keperluan Negara bagi sebesar-besarnya kemakmuran rakyat.

Tarif pajak adalah suatu penetepatan atau persentase berdasarkan undang-undang yang dapat digunakan untuk menghitung dan menentukan jumlah pajak yang harus dibayar, disetor atau dipungut oleh wajib pajak. manajemen pajak adalah sarana memenuhi kewajiban perpajakan dengan benar tetapi jumlah pajak yang dibayar dapat ditekan serendah mungkin untuk memperoleh laba dan likuiditas yang diharapkan. Tujuan dari manajemen pajak adalah menerapkan peraturan perpajakan secara benar dan usaha efisiensi untuk mencapai laba dan likuiditas yang seharusnya.

Tujuan diadakanya perencanaan pajak yaitu:

1. Memperkecil pajak yang ditanggung perusahaan,

2. Menghilangkan/menghapus pajak sama sekali,

3. Menghilangkan/menghapus pajak dalam tahun berjalan,

4. Menunda pengakuan penghasilan,

5. Mengubah penghasilan rutin berbentuk capital gain,

6. Memperluas bisnis atau melakukan ekspansi usaha dengan membentuk badan usaha baru,

7. Menghindari pengenaan pajak berganda,

8. Menghindari bentuk penghasilan yang bersifat rutin atau teratur

9. Menghindari bentuk penghasilan yang membentuk, memperbanyak atau mempercepat pengurangan pajak.

\section{Return On Assets}

ROA menunjukkan kemampuan perusahaan dengan menggunakan seluruh aktiva yang dimiliki untuk menghasilkan laba setelah pajak. Rasio ini penting bagi pihak manajemen untuk mengevaluasi efektivitas dan efisiensi manajemen dalam mengelola seluruh aktiva perusahaan. Semakin besar ROA, berarti semakin efisien penggunaan aktiva perusahaan.

Menurut Kasmir (2014:201) ROA merupakan rasio yang menunjukkan hasil atas jumlah aktiva yang digunakan dalam perusahaan. ROA dapat digunakan mengukur profitabilitas dan efesiensi tindakan-tindakan yang dilakukan oleh devisi/bagian yaitu dengan mengalokasikan semua biaya dan modal kedalam bagian yang bersangkutan. Munawir (2007)

\section{Kepemilikan Institusional}

Institusi sebagai pemilik saham dianggap lebih mampu dalam mendeteksi kesalahan yang terjadi. Hal ini dikarenakan investor institusi lebih berpengalaman dibandingkan dengan investor individual. Institusi sebagai investor yang sophisticated karena mempunyai kemampuan dalam memproses informasi dibandingkan dengan investor individual. Dengan demikian, akan semakin membatasi manajemen dalam memainkan angka dalam laporan keuangan menurut Saptantinah (2005) dalam cessy 2020.

Menurut Bushee dalam Cessy (2020) menyatakan bahwa kepemilikan institusional memiliki kemampuan untuk mengurangi insentif para manajer yang mementingkan diri sendiri melalui tingkat pengawasan yang intens. Kepemilikan institusional dapat menekan kecenderungan manajemen untuk memanfaatkan discretionary dalam laporan keuangan sehingga memberikan kualitas laba yang dilaporkan. Kepemilikan institusional memiliki 
kemampuan untuk mengendalikan pihak manajemen melalui proses monitoring secara efektif sehingga mengurangi tindakan manajemen melakukan manajemen laba. Persentase saham tertentu yang dimiliki oleh institusi dapat mempengaruhi proses penyusunan laporan keuangan yang tidak menutup kemungkinan terdapat akrualisasi sesuai kepentingan pihak manajemen.

Adapun pengertian kepemilikan institusional adalah kepemilikan saham yang dimiliki oleh pemerintah, bank, perusahaan asuransi, perusahaan dan investor luar negeri, kecuali kepemilikan individual investor. Kepemilikan institusional memilki arti yang luas dalam penelitian ini, sepanjang kepemilikan tersebut bukan kepemilikan individual dan memiliki saham diatas $5 \%$ maka termasuk dalam data kepemilikan institusional pada penelitian ini.

\section{Penghindaran Pajak (Tax avoidance)}

Menurut Mardiasmo (2011) pajak adalah iuran rakyat kepada kas Negara berdasarkan Undang-undang (yang dapat dipaksakan dengan tiada mendapat jasa timbale (kontra prestasi) yang langsung dapat ditunjukkan dan yang digunakan untuk membayar pengeluaran umum. Sedangkan menurut Waluyo (2011) pajak adalah iuran masyarakat kepada negara (yang dipaksakan) yang tentang oleh yang wajib membayarnya menurut peraturan-peraturan umum (undang-undang) dengan tidak mendapat prestasi kembali yang langsung dapat ditunjuk dan yang gunanya adalah untuk membiayai pengeluaran-pengeluaran umum berhubung tugas negara untuk menyelenggarakan pemerintahan.

Wajib pajak selalu menginginkan pembayaran pajak yang kecil, karena itulah tidak sedikit wajib pajak yang melakukan penghindaran pajak baik bersifat legal maupun ilegal. Penghindaran pajak yang bersifat legal disebut tax avoidance, sedangkan penghindaran pajak yang bersifat ilegal adalah penyelundupan pajak (tax evasion). Menurut Ernest R. Mortenson dalam zain (2008:49) penyeludupan pajak (tax evasion) adalah usaha yang tidak dapat dibenarkan berkenaan dengan kegiatan wajib pajak untuk lari dari pengenaan pajak. Sedangkan Penghindaran pajak ( tax avoidance) adalah berkenaan dengan pengaturan sesuatu peristiwa sedemikian rupa untuk meminimkan atau menghilangkan beban pajak dengan memerhatikan ada atau tidaknya akibat-akibat pajak yang ditinggalkannya.

\section{Kerangka berpikir}

Perusahaan akan menggunakan penghindaran pajak untuk menekan beban pajaknya agar tidak memberatkan keuangan perusahaan serta memanfaatkan sumber daya yang dimiliki oleh perusahaan untuk meminimalkan beban pajak dan mengefektifkan pembayaran pajaknya. Beberapa cara yang mungkin dilakukan perusahaan adalah dengan memanfaatkan ROA dan kepemilikan institusional.

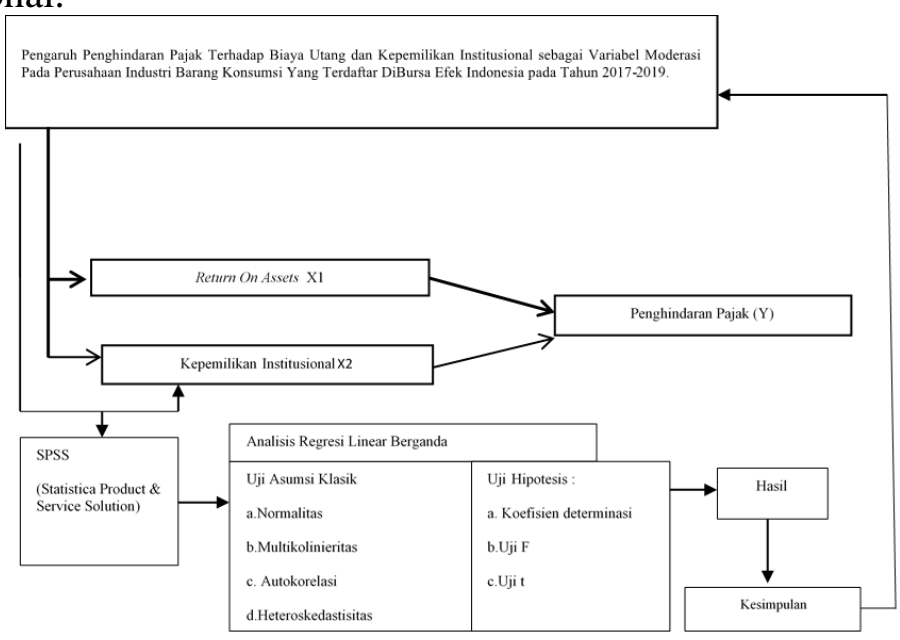

Gambar 2.1 Kerangka Berpikir 


\section{Hipotesis}

hipotesis merupakan jawaban sementara atas rumusan masalah yang masih harus dibuktikan kebenarannya secara empiris , maka hipotesis yang diajukan dalam penelitian ini adalah:

1. ROA berpengaruh negatif dan signifikan terhadap penghindaran pajak.

2. Kepemilikan Institusional berpengaruh negatif terhadap penghindaran pajak.

\section{METODE PENELITIAN}

\section{Populasi dan Sampel}

Populasi dalam penelitian ini adalah perusahaan industri barang konsumsi yang terdaftar di Bursa Efek Indonesia pada tahun 2017-2019 sebanyak 49 perusahaan. Perusahaan manufaktur pada tahun 2017-2019. Pemilihan sampel ditentukan secara purposive sampling dengan tujuan untuk mendapatkan sampel representif sesuai dengan keriteria yang ditentukan. Kriteria pengambilan sampel adalah sebagai berikut:

1. Perusahaan industri barang konsumsi yang terdaftar di Bursa Efek Indonesia tahun 2017-2019.

2. Perusahaan yang menyajikan laporan tahunan dan laporan keuangan yang lengkap pada periode penelitian tahun 2017-2019.

3. Perusahaan industri barang konsumsi yang tidak menghasilkan laba negatif selama periode penelitian tahun 2017-2019.

4. Perusahaan yang memiliki kelengkapan data variabel yang digunakan pada tahun 20172019.

\section{Operasional variabel}

\section{a. Penghindaran Pajak}

Penghindaran pajak adalah usaha mengurangi beban pajak dengan memanfaatkan potongan dan pengecualian yang diperbolehkan peraturan. Tax avoidance diproksikan dengan tarif pajak efektif (Effective tax rate). Tarif pajak efektif dihitung menambahkan beban pajak kini dan beban pajak tangguhan dibagi laba sebelum pajak. Beban pajak kini dan beban pajak tangguhan dihitung sesuai dengan peraturan perpajakan. Laba sebelum pajak merupakan laba yang didapat perusahaan yang dihitung sesuai dengan standar akuntansi keuangan. ETR di ukur dengan menggunakan rumus sesuai dengan penelitian Cessy yaitu sebagai berikut:

\section{b. Return On Assets}

$$
E T R=\frac{\text { Beban Pajak }}{\text { Laba sebelum pajak }} \times 100 \%
$$

ROA menunjukkan kemampuan perusahaan dengan menggunakan seluruh aktiva yang dimiliki untuk menghasilkan laba setelah pajak. ROA dihitung dengan rumus yang dikemukan oleh Kasmir (2014) yaitu sebagai berikut;

$$
R O A=\frac{\text { Laba Bersih setelah pajak }}{\text { Total Aset }} \mathrm{X} 100 \%
$$

\section{c. Kepemilikan Institusional}

Kepemilikan institusional merupakan kepemilikan saham perusahaan yang dimiliki oleh pemerintah, bank, perusahaan sekuritas, perusahaan asuransi dan investor luar negeri, kecuali kepemilikan investor individual. Kepemilikan institusional dihitung dengan rumus sesuai dengan penelitian Gusnurdiana yaitu sebagai berikut:

$$
K I=\frac{\text { jumlah saham yang dimiliki Institusi }}{\text { Jumlah Saham Yang Beredar }}
$$

\section{Teknik Analisa Data}

Teknik yang digunakan dalam penelitian ini adalah analisa regresi berganda . teknik analisa berganda berguna untuk menguji pengaruh variabel independen dan variabel dependen. Untuk 
mengetahui besarnya pengaruh variabel independen dan variabel dependen digunakan model sebagai berikut:

Keterangan :

$$
\mathrm{Y}=\alpha+\mathrm{b} 1 \mathrm{X} 1+\mathrm{b} 2 \mathrm{X} 2+\mathrm{e}
$$

Y : Penghindaran pajak

$\boldsymbol{\alpha} \quad$ : Konstanta

b1,b2 : Koefesien

$\mathrm{X} 1 \quad$ : Return On Assets

X2 : Kepemilikan Institusional

$\boldsymbol{e} \quad$ : error

\section{HASIL PENELITIAN DAN PEMBAHASAN}

\section{Pengujian Asumsi Klasik}

Uji asumsi klasik digunakan untuk memastikan bahwa uji normalitas, uji multikolonieritas dan uji heteroskedastisitas tidak terdapat dalam model yang digunakan dan data yang dihasilkan terdistribusi normal. Asumsi klasik dapat dijabarkan sebagai berikut:

\section{a) Uji Normalitas}

Uji normalitas dilakukan untuk menguji apakah dalam model regresi variabel pengganggu (residual) terdistribusi secara normal. Data yang terdistribusi normal akan memperkecil kemungkinan terjadinya bias. Pengujian normalitas dilakukan dengan menggunakan metode analisis statistik.

Tabel 1 One Sample Kolmogorov-Smirnov Test (sebelum outlier)

\begin{tabular}{|c|c|c|}
\hline \multicolumn{3}{|c|}{ One-Sample Kolmogorov-Smirnov Test } \\
\hline \multirow{2}{*}{\multicolumn{2}{|c|}{$\mathrm{N}$}} & Unstandardized Residual \\
\hline & & 84 \\
\hline \multirow{2}{*}{$\begin{array}{l}\text { Normal } \\
\text { Parameters }\end{array}$} & Mean & .0000000 \\
\hline & $\begin{array}{l}\text { Std. } \\
\text { Deviation }\end{array}$ & .10095656 \\
\hline \multirow{3}{*}{$\begin{array}{l}\text { Most Extreme } \\
\text { Differences }\end{array}$} & Absolute & .191 \\
\hline & Positive & .191 \\
\hline & Negative & -.151 \\
\hline \multicolumn{2}{|l|}{ Test Statistic } & .191 \\
\hline \multicolumn{2}{|c|}{ Asymp. Sig. (2-tailed) } & $.000^{\mathrm{c}}$ \\
\hline \multicolumn{3}{|c|}{ a. Test distribution is Normal. } \\
\hline \multicolumn{3}{|c|}{ b. Calculated from data. } \\
\hline
\end{tabular}

Sumber: Hasil Olahan SPSS 25

Pada tabel 1 dapat kita lihat bahwa hasil uji normalitas menghasilkan angka signifikansi sebesar 0,000 yang menunjukkan data tidak terdistribusi normal. Kemudian dilakukan pencarian data yang memiliki data outlier yang memiliki karateristik yang terlihat sangat berbeda jauh dari observasi-observasi lainnya dan muncul dalam bentuk nilai ekstrim yaitu memiliki nilai yang terlalu tinggi dan juga terlalu rendah. Hasil normalitas setelah lakukan treatment tersebut adalah pada tabel 4.9 sebagai berikut: 
Tabel 2 Hasil Uji One Sample Kolmogorov-Smirnov (setelah outlier)

\begin{tabular}{|c|c|c|c|}
\hline \multicolumn{4}{|c|}{ One-Sample Kolmogorov-Smirnov Test } \\
\hline & & & Unstandardized Residual \\
\hline \multicolumn{3}{|l|}{$\mathrm{N}$} & 56 \\
\hline \multirow{2}{*}{$\begin{array}{l}\text { Normal } \\
\text { Parameters } \\
\text { a,b }\end{array}$} & \multicolumn{2}{|l|}{ Mean } & .0000000 \\
\hline & \multicolumn{2}{|c|}{ Std. Deviation } & .02946759 \\
\hline \multirow{3}{*}{$\begin{array}{l}\text { Most } \\
\text { Extreme } \\
\text { Differences }\end{array}$} & \multicolumn{2}{|l|}{ Absolute } & .174 \\
\hline & \multicolumn{2}{|l|}{ Positive } & .174 \\
\hline & \multicolumn{2}{|l|}{ Negative } & -.114 \\
\hline \multicolumn{3}{|c|}{ Test Statistic } & .174 \\
\hline \multicolumn{3}{|c|}{ Asymp. Sig. (2-tailed) } & $.000^{\mathrm{c}}$ \\
\hline \multirow{3}{*}{$\begin{array}{l}\text { Monte } \\
\text { Carlo Sig. } \\
\text { (2-tailed) }\end{array}$} & \multicolumn{2}{|l|}{ Sig. } & $.060^{\mathrm{d}}$ \\
\hline & \multirow{2}{*}{$\begin{array}{l}99 \% \\
\text { Confidenc } \\
\text { e Interval }\end{array}$} & Lower Bound & .054 \\
\hline & & Upper Bound & .066 \\
\hline \multicolumn{4}{|c|}{ a. Test distribution is Normal. } \\
\hline \multicolumn{4}{|c|}{ b. Calculated from data. } \\
\hline \multicolumn{4}{|c|}{ c. Lilliefors Significance Correction. } \\
\hline \multicolumn{4}{|c|}{ d. Based on 10000 sampled tables with starting seed 2000000.} \\
\hline
\end{tabular}

Sumber: Hasil Olahan SPSS 25

Dari tabel 2 diatas dapat kita lihat uji normalitas menunjukkan nilai signifikan 0,060 yang berarti lebih besar dari 0,05 sehingga menunjukkan data residual berdistribusi normal.

\section{b) Uji Multikolinearitas}

Uji multikolinearitas bertujuan untuk menguji apakah model regresi ditemukan adanya korelasi antar variabel bebas (independen). Model regresi yang baik seharusnya tidak terjadi korelasi di antara variabel independennya Ghozali, (2018; 107-111). Untuk mendeteksi adanya masalah multikolinearitas adalah dengan menggunakan perhitungan nilai tolerance dan variance inflation factor (VIF).

Tabel 3 Hasil Uji Multikolinearitas

\begin{tabular}{|c|c|c|c|c|c|c|c|c|}
\hline \multicolumn{9}{|c|}{ Coefficients $^{\mathrm{a}}$} \\
\hline & & \multicolumn{2}{|c|}{$\begin{array}{c}\text { Unstandardized } \\
\text { Coefficients }\end{array}$} & \multirow{2}{*}{$\begin{array}{c}\text { Standardized } \\
\text { Coefficients } \\
\text { Beta }\end{array}$} & \multirow[b]{2}{*}{$\mathrm{t}$} & \multirow[b]{2}{*}{ Sig. } & \multicolumn{2}{|c|}{$\begin{array}{c}\text { Collinearity } \\
\text { Statistics }\end{array}$} \\
\hline \multicolumn{2}{|c|}{ Model } & B & $\begin{array}{l}\text { Std. } \\
\text { Error }\end{array}$ & & & & Tolerance & VIF \\
\hline \multirow[t]{3}{*}{1} & (Constant) & .260 & .013 & & 19.850 & .000 & & \\
\hline & ROA & .073 & .054 & .196 & 1.338 & .186 & .848 & 1.179 \\
\hline & $\mathrm{KI}$ & -.021 & .019 & -.160 & -1.092 & .280 & .848 & 1.179 \\
\hline
\end{tabular}

Sumber: Hasil Olahan SPSS 25

Berdasarkan tabel 3 dapat kita lihat bahwa nilai Tolerance menunjukkan tidak ada variabel independen yang memiliki nilai tolerance kurang dari 0.10 yang berarti tidak ada korelasi antar variabel independen yang nilainya lebih dari $95 \%$. Hasil nilai variance inflation 
factor (VIF) juga menunjukkan hal yang sama tidak ada satu variabel independen yang memiliki nilai VIF lebih dari 10. Dengan demikian, dapat disimpulkan bahwa tidak ada multikolonieritas antar variabel independen dalam model regresi.

\section{c) Autokorelasi}

Uji autokorelasi bertujuan untuk menguji apakah dalam model regresi linear ada korelasi antara kesalahan pengganggu pada periode $t$ dengan kesalahan pengganggu pada periode $\mathrm{t}-1$ (sebelumnya). Jika terjadi korelasi, maka dinamakan ada problem autokorelasi. Autokorelasi muncul karena observasi yang berurutan dan berkaitan satu sama lainnya.

Tabel 4. Pengambilan Keputusan Durbin Watson

\begin{tabular}{|l|c|c|}
\hline \multicolumn{1}{|c|}{ Hipotesis Nol } & Keputusan & Jika \\
\hline Tidak ada autokorelasi positif & Tolak & $0<\mathrm{d}<\mathrm{dl}$ \\
\hline Tidak ada autokorelasi positif & No desicison & $\mathrm{dl} \leq \mathrm{d} \leq \mathrm{du}$ \\
\hline idak ada autokorelasi Negatif & Tolak & $4-\mathrm{dl}<\mathrm{d}<4$ \\
\hline $\begin{array}{c}\text { Tidak ada autokorelasi negatif } \\
\text { Tidak ada autokorelasi positif }\end{array}$ & No desicison & $4-\mathrm{du} \leq \mathrm{d} \leq 4-\mathrm{dl}$ \\
\hline
\end{tabular}

Sumber : (Ghozali, 2018:112)

Tabel 5 Uji Autokorelasi

\begin{tabular}{|l|c|c|c|c|r|}
\hline \multicolumn{7}{|c|}{ Model Summary $^{\mathbf{b}}$} & $\begin{array}{r}\text { Durbin- } \\
\text { Model }\end{array}$ \\
\hline 1 & $\mathrm{R}$ & R Square & Adjusted R Square & Std. Error of the Estimate & Watson \\
\hline \multicolumn{7}{|l|}{$\begin{array}{l}9^{\mathrm{a}} \\
\text { a. Predictors: (Constant), KI, ROA }\end{array}$} & .003 & .03001842943 & 2.025 \\
\hline \multicolumn{2}{|l}{ b. Dependent Variable: Penghindaran Pajak } & & \\
\hline
\end{tabular}

Sumber: Hasil Olahan SPSS 25

Berdasarkan tabel 5 Nilai DW sebesar 2.025 , nilai ini akan kita bandingkan dengan nilai tabel dengan menggunakan nilai signifikan 5\%, jumlah sampel $(\mathrm{n})=56$ dan jumlah variabel independen $(K)=2$.

Tabel 6 Durbin Watson Test

\begin{tabular}{|c|c|c|c|c|}
\hline & $\mathrm{K}=2$ & & & \\
\hline $\mathrm{N}$ & $\mathrm{Dl}$ & $\mathrm{Du}$ & $4-\mathrm{Dl}$ & $4-\mathrm{Du}$ \\
\hline 56 & 1.4954 & 1.6430 & 2.5046 & 2.357 \\
\hline
\end{tabular}

Sumber: Hasil Olahan tabel Durbin Watson

Berdasarkan tabel 6 , nilai DW variabel penghindaran pajak adalah 2.025. nilai ini dibandingkan dengan nilai DW dan tabel DW. Dengan jumlah sampel penelitian (N) 56 dan jumlah variabel independen $(\mathrm{k}=2)$ maka diproleh nilai $\mathrm{dU}=1.4954$ dan $\mathrm{dL}=1.6430$ pada tabel DW. Dengan demikian untuk variabel dependen penghindaran pajak perusahaan $\mathrm{du}<\mathrm{dw}<4$-du $(1.6430<2.025<2.357)$, sehingga dapat disimpulkan bahwa tidak terdapat autokorelasi baik positif ataupun negatif. Dengan demikian model regresi linier layak pada penelitian ini karena data pada penelitian ini bebas dari masalah autokorelasi.

\section{d) Uji Heteroskedastisitas}

Uji heteroskedastisitas bertujuan menguji apakah dalam model regresi terjadi ketidaksamaan variance dari residual satu pengamatan ke pengamatan yang lain. Jika variance dari residual satu pengamatan ke pengamatan lain tetap, maka disebut 
homoskedastisitas dan jika berbeda disebut heteroskedastisitas. Model regresi yang baik adalah yang homoskedastisitas atau tidak terjadi heteroskedastisitas (Ghozali, 2018;137).

Tabel 7 Hasil Uji Heteroskedastisitas

\begin{tabular}{|c|c|c|c|c|c|c|}
\hline \multicolumn{7}{|c|}{ Coefficients $\mathbf{s}^{\mathrm{a}}$} \\
\hline & & \multicolumn{2}{|c|}{$\begin{array}{c}\text { Unstandardized } \\
\text { Coefficients }\end{array}$} & \multirow{2}{*}{$\frac{\text { Standardized Coefficients }}{\text { Beta }}$} & \multirow[b]{2}{*}{ t } & \multirow[b]{2}{*}{ Sig. } \\
\hline \multicolumn{2}{|c|}{ Model } & B & Std. Error & & & \\
\hline \multirow[t]{3}{*}{1} & (Constant) & .009 & .010 & & .885 & .380 \\
\hline & ROA & .065 & .042 & .221 & 1.521 & .134 \\
\hline & $\mathrm{KI}$ & .001 & .015 & .010 & .068 & .946 \\
\hline
\end{tabular}

a. Dependent Variable: abs_res

Sumber: Hasil Olahan SPSS 25

Berdasarkan tabel 7 diatas dapat kita lihat bahwa nilai signifikan untuk ROA 0.134 ini jauh lebih besar dari 0,05 dan untuk kepemilikan institusional 0.946 juga jauh lebih besar dari 0,05 sehingga dapat disimpulkan tidak adanya heteroskedastisitas.

\section{Model Penelitian}

\section{a. Uji Regresi Linier Berganda}

Dalam penelitian ini menggunakan analisis regresi linier berganda. Analisis ini digunakan untuk mengukur kekuatan dua variabel atau lebih serta menunjukkan arah hubungan antar variabel dependen dengan variabel independen.

Berdasarkan hasil penelitian dengan menggunakan program SPSS versi 25 diperoleh output regresi linier berganda sebagai berikut:

Tabel 8 Hasil uji regresi linier berganda

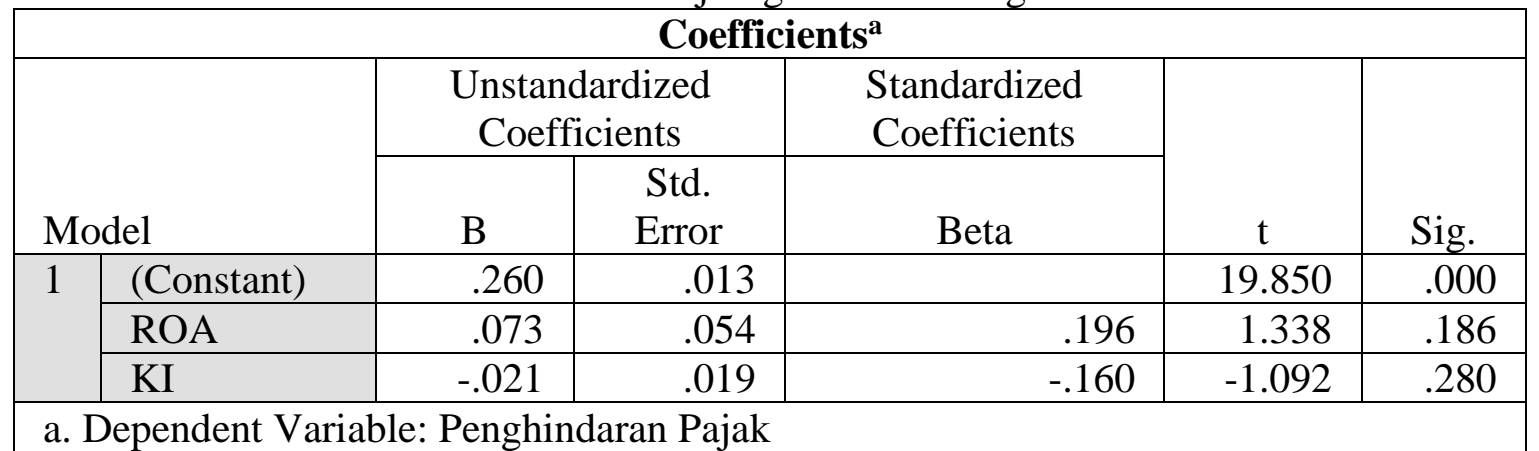

Sumber: Hasil Olahan SPSS 25

Berdasarkan tabel 8 diatas hasil analisis uji regresi linier berganda, maka diperoleh persamaan sebagai berikut :

$\mathrm{Y}=\alpha+\mathrm{b} 1 \mathrm{X} 1+\mathrm{b} 2 \mathrm{X} 2+\mathrm{e}$

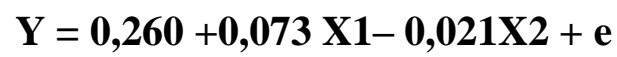

Tabel 8 menunjukkan prediksi masing-masing variabel. Dari persamaan regresi berganda diatas dapat diambil kesimpulan sebagai berikut;

1. Konstanta sebesar 0,260 menyatakan bahwa jika tidak ada ROA dan kepemilikan institusinal maka penghindaran pajak (Y) nilainya yaitu 0,260 satuan.

2. Koefesien regresi variabel ROA sebesar 0,073 dengan arah positif yang berarti bahwa setiap kenaikan 1 satuan pada ROA akan mengikuti kenaikan nilai dari penghindaran pajak sebesar 0,073 satuan. 
3. Koefesien regeresi variabel kepemilikan institusional sebasar-0,021 dengan arah negatif yang berarti bahwa setiap kenaikan 1 satuan pada kepemilikan institusional akan membuat penurunan nilai dari penghindaran pajak sebesar 0,021 satuan.

\section{b. Uji Koefesien Determinasi $\left(\boldsymbol{R}^{2}\right)$}

Koefisien determinasi $\left(R^{2}\right)$ digunakan untuk mengukur seberapa jauh kemampuan model dalam menjelaskan variasi variabel terikat (Ghozali, 2018;97). Nilai koefisien determinasi $\left(R^{2}\right)$ adalah antara nol dan satu. Apabila nilai $R^{2}$ kecil maka kemampuan variabel-variabel independen dalam menjelaskan variasi variabel dependen sangat terbatas. Sedangkan, apabila nilai $R^{2}$ mendekati satu berarti variabel-variabel independen memberikan hampir semua informasi yang dibutuhkan untuk memprediksi variasi variabel dependen.

Tabel 9 Hasil Uji Koefesien Determinasi $\left(R^{2}\right)$

\begin{tabular}{|l|c|c|r|r|}
\hline \multicolumn{5}{|c|}{ Model Summary $^{\mathbf{b}}$} \\
\hline Model & $\mathrm{R}$ & $\mathrm{R}$ Square & Adjusted R Square & Std. Error of the Estimate \\
\hline 1 & .199 & .039 & .003 & .03001842943 \\
\hline a. Predictors: (Constant), KI, ROA \\
\hline
\end{tabular}

Sumber: Hasil Olahan SPSS 25

Berdasarkan hasil perhitungan tabel 9 dapat diketahui bahwa nilai $\mathrm{R}$ square sebesar 0,039. Hal ini menunjukkan bahwa besar presentase variabel dependen penghindaran pajak sebesar 3,9\% dipengaruhi oleh variabel independen yaitu ROA dan Kepemilikan Institusional. Dan sisanya sebesar $96,1 \%$ dipengaruhi oleh faktor - faktor lain diluar model.

\section{Pengujian Hipotesis}

a. Uji Statistik F

Uji ini digunakan untuk menguji pengaruh variabel indenden terhadap variabel dependen secara simultan (bersama-sama).

Tabel 10 Hasil Uji Stastistik F

\begin{tabular}{|l|l|r|r|r|r|c|}
\hline \multicolumn{7}{|c|}{ ANOVA $^{\mathbf{a}}$} \\
\hline \multicolumn{2}{|l|}{ Model } & Sum of Squares & \multicolumn{1}{c|}{ df } & Mean Square & F & Sig. $^{-1}$ \\
\hline \multirow{3}{*}{1} & Regression & .002 & 2 & .001 & 1.087 & $.344^{\mathrm{b}}$ \\
\cline { 2 - 7 } & Residual & .048 & 53 & .001 & & \\
\cline { 2 - 7 } & Total & .050 & 55 & & & \\
\hline
\end{tabular}

Sumber: Hasil Olahan SPSS 25

Berdasarkan uji f diatas dapat dijelaskan bahwa ROA dan kepemilikan institusional dengan nilai f hitung sebesar 1,087 dan tingkat signifikan sebesar 0,344. Nilai f hitung sebesar 1,087 lebih kecil dari f tabel sebesar 3,172 dan tingkat signifikan nya sebesar 0,344 lebih besar dari 0,05. dengan demikian ROA dan kepemilikan institusional tidak berpengaruh signifikan terhadap penghindaran pajak.

b. Uji Statistik t

Uji t dilakukan untuk mengetahui pengaruh antara ROA dan kepemilikan institusional secara parsial.

Tabel 11 Hasil Uji Statistik t

\begin{tabular}{|l|c|c|c|c|}
\hline \multicolumn{5}{|c|}{ Coefficients $^{\mathbf{a}}$} \\
\hline \multirow{3}{*}{ Model } & $\begin{array}{c}\text { Unstandardized } \\
\text { Coefficients }\end{array}$ & $\begin{array}{c}\text { Standardized } \\
\text { Coefficients }\end{array}$ & $\mathrm{t}$ & Sig. \\
\hline
\end{tabular}




\begin{tabular}{|c|l|r|r|r|r|r|}
\hline \multicolumn{2}{|c|}{} & \multicolumn{1}{|c|}{ B } & Std. Error & Beta & & \\
\hline \multirow{2}{*}{1} & (Constant) & .260 & .013 & & 19.850 & .000 \\
\cline { 2 - 7 } & ROA & .073 & .054 & .196 & 1.338 & .186 \\
\cline { 2 - 7 } & KI & -.021 & .019 & -.160 & -1.092 & .280 \\
\hline
\end{tabular}

a. Dependent Variable: Penghindaran Pajak

Sumber: Hasil Olahan SPSS 25

Berdasarkan tabel diatas dapat dijelaskan bahwa:

1. Return On Assets

Variabel ROA (X1) dengan nilai t hitung 1,338 dan tingkat signifikan sebesar 0,186. Nilai t hitung sebesar 1,338 lebih kecil dari t tabel sebesar 1,674 dan tingkat signifikan sebesar 0,186 lebih besar dari 0,05. Ini berarti bahwa ROA X1 berpengaruh positif dan tidak signifikan. Dengan demikian hipotesis yang menyatakan ROA berpengaruh positif dan signifikan terhadap penghindaran pajak ditolak.

2. Kepemilikan Institusional

Variabel kepemilikan Institusional (X2) dengan nilai t hitung -1,092 dan tingkat signifikan sebesar 0,280. Nilai t hitung sebesar $-1,092$ lebih kecil dari t tabel sebesar 1,674 dan tingkat signifikan sebesar 0,280 lebih besar dari 0,05. Ini berarti bahwa kepemilikan institusional (X2) berpengaruh negatif dan tidak signifikan. Dengan demikian hipotesis yang menyatakan kepemilikan institusional berpengaruh negatif dan signifikan terhadap penghindaran pajak ditolak.

\section{HASIL DAN PEMBAHASAN}

\section{a. Pengaruh Return On Assets terhadap Penghindaran Pajak}

ROA (X1) dengan nilai t hitung 1,338 dan tingkat signifikan sebesar 0,186 . Nilai $t$ hitung sebesar 1,338 lebih kecil dari t tabel sebesar 1,674 dan tingkat signifikan sebesar 0,186 lebih besar dari 0,05. Ini berarti bahwa ROA X1 tidak berpengaruh positif terhadap penghindaran pajak, sehingga H1 Ditolak.

Berdasarkan data penelitian, ROA berpengaruh positif dan tidak signifikan terhadap penghindaran pajak. Hal ini disebabkan karena aktiva milik perusahaan sampel secara ratarata yaitu berupa mesin, peralatan, maupun bangunan memiliki periode fungsional lebih dari 1 tahun. Karena digunakan secara berkala dalam waktu yang lama, nilai aktiva tetap biasanya akan mengalami penyusutan atau depresiasi. Semakin lamanya umur yang digunakan maka besarnya biaya depresiasi akan semakin kecil. Jika peralatan kantor atau mesin dapat digunakan selama 4 tahun maka tarif depresiasinya 25\%, sedangkan bangunan memiliki periode fungsional selama 20 tahun dengan besarnya biaya depresiasi 5\%. Hal ini menimbulkan beban penyusutan yang tinggi dan akhirnya mengurangi laba kena pajak perusahaan.

Hasil penelitian ini konsisten dengan hasil penelitian yang dilakukan oleh penelitian sebelumnya yaitu Jannah (2019) yang mengungkapkan bahwa return on assets tidak berpengaruh terhadap penghindaran pajak.

Hasil ini berbeda dengan hasil penelitian yang dilakukan oleh Gusnurdiana, Halimahtusadiah dan Sofianty (2018), Fadila (2017) Faizah (2017) yang menyimpulkan bahwa ROA berpengaruh terhadap penghindaran pajak.

\section{b. Pengaruh Kepemilikan Institusional terhadap Penghindaran Pajak}

Kepemilikan Institusional (X2) dengan nilai t hitung -1,092 dan tingkat signifikan sebesar 0,280. Nilai t hitung sebesar -1,092 lebih kecil dari t tabel sebesar 1,674 dan tingkat signifikan sebesar 0,280 lebih besar dari 0,05. Ini berarti bahwa kepemilikan institusional X2 tidak berpengaruh negatif terhadap penghindaran pajak, sehingga $\mathbf{H 2}$ ditolak. 
Berdasarkan data penelitian kepemilikan institusional berpengaruh negatif dan tidak signifikan terhadap penghindaran pajak. Hal ini disebabkan karena para investor institusional dalam melaksanakan fungsi monitoring dalam perusahaan belum optimal sehingga para manajemen perusahaan yang bertindak atas kepentingan pribadi untuk mendapatkan keuntungan yang besar bisa dengan bebas melakukan penghindaran pajak.

Hasil ini konsisten dengan hasil penelitian yang dilakukan oleh Jannah (2019), dan Faizah (2017) yang menyimpulkan bahwa kepemilikan institusional tidak berpengaruh terhadap penghindaran pajak.

Hal ini berbeda dengan hasil penelitian yang dilakukan oleh Gusnurdiana, Halimahtusadiah dan Sofianty (2018) dan Fadila (2017) yang menyimpulkan bahwa kepemilikan institusional berpengaruh signifikan terhadap penghindaran pajak.

\section{KESIMPULAN DAN SARAN}

\section{Kesimpulan}

Berdasarkan hasil penelitian dan pembahasan mengenai pengaruh Return On Assets dan kepemilikan institusional terhadap penghindaran pajak pada perusahaan industri barang konsumsi yang terdaftar di Bursa Efek Indonesia tahun 2017-2019 maka diproleh kesimpulan sebagai berikut:

1. Return On Assets berpengaruh positif dan tidak signifikan terhadap penghindaran pajak .

2. Kepemilikan Institusional berpengaruh negatif dan tidak signifikan terhadap penghindaran pajak.

\section{Saran}

Bagi peneliti selanjutnya diharapkan dapat menambahkan variabel lain seperti kepemilikan manajerial, kualitas audit, serta karakteristik perusahaan lainnya dan menambah jumlah sampel perusahaan, memperpanjang periode pengamatan, dan meneliti studi kasus sektor lain sehingga mencakup lebih luas lagi dalam penelitian.

\section{DAFTAR PUSTAKA}

Bernardhi, Riza dan D, Muid. 2014. Pengaruh Kepemilikan Manajerial, Lembaga Kepemilikan, Kebijakan Dividen, Leverage, dan Ukuran Perusahaan Terhadap Nilai Perusahaan. Jurnal. Semarang: Universitas Dipenogoro. (https://ejournal3.undip.ac.id/index.php/accounting/article/view/6029), (diakses pada 20 februari 2021)

Darmadi, Iqbal Nul Hakim. 2013. Analisis Faktor yang Mempengaruhi Manajemen Pajak dengan Indikator Tarif Pajak efektif. Skripsi. Semarang: Fakultas Ekonomika dan Bisnis Universitas Diponegoro.

Dyreng, S.D., Hanlon, M. \& Maydew, EL. 2008. Long-run Corporate Tax avoidance.The Accounting Review, 83(1), 61-82 (Diakses pada 13 maret 2021).

Fadila, Melisa. 2017. Pengaruh Return On Assets, Leverage, Ukuran perusahaan Konpensasi Rugi Fiskal, Kepemilikan Institusional, dan Koneksi Politik Terhadap Penghindaran Pajak Studi Empiris Pada Perusahaan Manufaktur Yang terdaftar Di BEI tahun 20112015. Skripsi. Pekan Baru: Fakultas Ekonomi Universtias Riau.

Ghozali, Imam. 2018. Analisis Multivariate Program IBM SPSS 25. Semarang: Badan Penerbit Universitas Diponegoro.

Gusnurdiana, Fariz. Elly Halimahtusadiah. Dan Diamonalisa Sofianty. 2018. Pengaruh Return On Assets (ROA) dan Kepemilikan Institusional terhadap Penghindaran Pajak. Jurnal. Bandung: Prodi Akuntansi Fakultas Ekonomi Dan Bisnis Universitas Islam Bandung. 
Hery. 2015. Analisis Laporan Keuangan. Yogyakarta: CAPS (Center For Academic Publishing Service)

Holbeche, Linda. 2005. The High Performance Organization: Creating Dynamic Stability and Suistainble Succsess. Oxford: Elsevier Butterworth-Heinemann.

Indriantoro, Nur dan Bambang Supomo. 2012. Metodologi Penelitian Bisnis (Untuk Akuntansi dan Manajemen). Yogyakarta. Edisi Pertama. BPFE-UGM.

Jannah, Afiati, Nur. 2019.Pengaruh Return On Assets, Leverage, Sales Growth, dan Kepemelilikan Institusional Terhadap Tax Avoidance (Study Pada Perusahaan LQ-45 Yang Terdaftar di Bursa Efek Indonesia Tahun 2015-2018. Skripsi. Jawa Tengah: Universitas Panca Sakti Tegal.

Jensen, M.C. dan W.H. Meckling. 1976. "Theory of the Firm: Managerial Behaviour, Agency Cost, and Ownership Structure." Journal of Financial Economic, Vol. 3

Kasmir. 2014. Analisis Laporan keuangan. Catatan ke-7. Jakarta: Pt Raja Grapindo Persada. Mardiasmo. 2011. Perpajakan. Edisi revisi. Andi: Yogyakarta.

Messier,W.f, S.M, Glover, D.F. Prawitt. 2006. Auditing \& Assuarance Services: A systematic. 4 edition. McGraW hill Press.

Munawir, S. 2007. Analisis Laporan Keuangan. Edisi keempat. Yogyakarta: Liberty.

Ngadiman dan Puspitasari, C. 2014. Pengaruh Leverage, Kepemilikan Institusional, dan Ukuran Perusahaan terhadap Penghindaran Pajak (Tax Avoidance) pada Perusahaan Sektor Manufaktur yang Terdaftar di Bursa Efek Indonesia 2010-2012. Jurnal Akuntansi: 8(3), hal.408-421.

Nur, Afiati, Jannah. 2019. Pengaruh Return On Assets, Leverage, Salesh Growth, Dan Kepemilikan Institusional, Terhadap Tax Avoidance ( Studi Pada Perusahaan LQ-45 Yang Terdaftar Dibursa Efek Indonesia Tahun 2015-2018. Skripsi. Jawa Tengah. Fakultas Ekonomi dan Bisnis Universitas Pancasakti Tegal.

Nur, Siti, Faizah. Dan Vidya Vitta Adhivinna. 2017. Pengaruh Retrun On Assets, Leverage, Kepemilikan Institusional, dan Ukuran Perusahaan terhadap Tax Avoidance. Jurnal. Yogyakarta: Universitas PGRI Yogyakarta.

Prastowo D, Dwi. 2015. Analisis Laporan Keuangan. Yogyakarta: UPP STIM YKPN

Republik Indonesia. Undang-undang Nomor 28 Tahun 2007. Perubahan Ketiga atas UndangUndang Nomor 6 Tahun 1983 tentang Ketentuan Umum dan Tata Cara Perpajakan.

Scott, William R. 2003. Financial Accounting Theory. 3rd edition. USA: Prentice Hall.

Suandy, Erly. 2008. Perencanaan Pajak. Jakarta: Salemba Empat.

Sudana, I Made. 2015. Manajemen Keuangan Perusahaan. Edisi kedua. Jakarta: Erlangga.

Sugiyono. 2007. Metodologi Penelitian Kuantitatif dan R\&D. Bandung: Alfabeta.

Tarjo. 2008. Pengaruh Konsentrasi Kepemilikan Institusional dan Leverage terhadap Manajemen Laba, Nilai Pemegang Saham, Serta Cost of Equity Capital. Simposium Nasional Akuntansi XI, Pontianak (Diakses pada 6 februari 2021).

Undang-Undang Republik Indonesia Nomor 16 Tahun 2009 tentang KetentuanUmum dan Tatacara Perpajakan.

Waluyo. 2011. Perpajakan Indonesia. Jakarta: Salemba empat. Edisi 11.

www.idx.co.id/, (diakses 27 Februari 2021.)

www.kemenkeu.go.id./, (diakses 25 Februari 2021)

Zain, Mohammad. (2008). Manajemen Perpajakan. Jakarta: Salemba Empat,Edisi 3.

Zebua, Cessy, Agnes. 2020. Pengaruh Good Corporate Governance Terhadap Tax avoidance Perusahaan pada Perusahaan Pertambangan yang Terdaftar di Bursa Efek Indonesia Pada tahun 2017-2019. Skripsi. Medan: Universitas Katolik Santo Thomas Medan. 